\title{
"Unobservable characteristics of board directors and the performance of financial services firms in Nigeria"
}

\begin{tabular}{|c|c|}
\hline AUTHORS & $\begin{array}{l}\text { Henry Osahon Osazevbaru } \\
\text { Emmanuel Mitaire Tarurhor (id https://orcid.org/0000-0002-7474-0752 }\end{array}$ \\
\hline ARTICLE INFO & $\begin{array}{l}\text { Henry Osahon Osazevbaru and Emmanuel Mitaire Tarurhor (2020). } \\
\text { Unobservable characteristics of board directors and the performance of financial } \\
\text { services firms in Nigeria. Investment Management and Financial Innovations, } \\
\text { 17(4), 378-388. doi:10.21511/imfi.17(4).2020.32 }\end{array}$ \\
\hline DOI & http://dx.doi.org/10.21511/imfi.17(4).2020.32 \\
\hline RELEASED ON & Friday, 18 December 2020 \\
\hline RECEIVED ON & Saturday, 07 November 2020 \\
\hline \multirow[t]{2}{*}{ ACCEPTED ON } & Wednesday, 16 December 2020 \\
\hline & $(\mathrm{cc}) \mathrm{EY}$ \\
\hline LICENSE & $\begin{array}{l}\text { This work is licensed under a Creative Commons Attribution } 4.0 \text { International } \\
\text { License }\end{array}$ \\
\hline JOURNAL & "Investment Management and Financial Innovations" \\
\hline ISSN PRINT & $1810-4967$ \\
\hline ISSN ONLINE & $1812-9358$ \\
\hline PUBLISHER & LLC "Consulting Publishing Company "Business Perspectives" \\
\hline FOUNDER & LLC “Consulting Publishing Company "Business Perspectives" \\
\hline & $\begin{array}{l}= \pm: \\
= \pm=-\end{array}$ \\
\hline NUMBER OF REFERENCES & NUMBER OF FIGURES \\
\hline 40 & 0 \\
\hline
\end{tabular}

(c) The author(s) 2021. This publication is an open access article. 


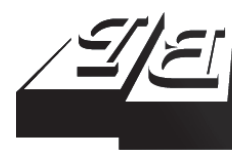

\section{BUSINESS PERSPECTIVES}

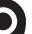

LLC "CPC "Business Perspectives"

Hryhorii Skovoroda lane, 10,

Sumy, 40022, Ukraine

www.businessperspectives.org
Received on: $7^{\text {th }}$ of November, 2020 Accepted on: $16^{\text {th }}$ of December, 2020 Published on: $18^{\text {th }}$ of December, 2020

(C) Henry Osahon Osazevbaru, Emmanuel Mitaire Tarurhor, 2020

Henry Osahon Osazevbaru, Ph.D., Lecturer, Department of Business Administration, Faculty of Social Sciences, Delta State University, Abraka, Delta State, Nigeria.

Emmanuel Mitaire Tarurhor, Ph.D., Lecturer, Department of Business Administration, Faculty of Social Sciences, Delta State University, Abraka, Delta State, Nigeria. (Corresponding author)

\section{UNOBSERVABLE CHARACTERISTICS OF BOARD DIRECTORS AND THE PERFORMANCE OF FINANCIAL SERVICES FIRMS IN NIGERIA}

\begin{abstract}
This paper examines the intricate link between unobservable characteristics of directors on the corporate board and firm performance. It aims to extend the literature on corporate governance and firm strategic performance from the perspective of emerging African economies. A mix of performance measures were used (Tobin Q, return on assets, and share price) and unobservable characteristics were captured as a stochastic element or heterogeneity of observable board characteristics (board activity, gender diversity, size, and independence). The study applied non-linear generalized auto-regressive conditional heteroscedasticity model to examine the data set consisting of 299 firm-year observations from 23 financial firms listed on the Nigerian Stock Exchange from 2006 to 2018. Positive skewness and leptokurtic distribution were found for all the variables. Correlation matrix revealed no multicollinearity, as the highest value was 0.2386 . Empirical results suggest that unobservable characteristics significantly and positively influence firm performance as measured by return on assets and share price. This is because the coefficient of the lagged-value of the variance scaling parameter is positive and significant at the $1 \%$ level. However, with respect to Tobin Q measure, the result was positive but not significant at the $5 \%$ level. Implicitly, the result is sensitive to performance proxies. Accordingly, this study concludes that unobservable characteristics drive firm performance. It is recommended that boards and regulators should pay attention to unobservable characteristics.
\end{abstract}

\section{Keywords}

affect, commitment, diversity, emotion, expertise, GARCH, governance, independence, opportunism

JEL Classification M14, G20, G34

\section{INTRODUCTION}

The need for effective corporate governance in companies is not unconnected with a financial scandal and eventual collapse of some corporate giants like Enron and WorldCom. The recognition of "not too big to fail" in the corporate world has led to the institution of corporate governance mechanism in organizations. Different countries now have formalized codes of corporate governance to regulate corporate affairs (Akpan \& Amran, 2014; Imade, 2019). Regulation of corporate affairs is necessary to mitigate the conflict of interest between the owners and managers. The separation of ownership from control does lead to an agency problem when managers engage in information asymmetry (Pereira \& Filipe, 2014). To mitigate this, Garcia-Martin and Herrero (2018) suggest that the board of directors should come in as an essential element of corporate governance.

Basically, boards are charged with monitoring and supervision, preventing management opportunism, and providing decision-makers with advice to improve strategic performance (Horvath \& Spirollari, 2012). The performance of a board largely depends on the character of an individual director (Fernau, 2013). In this regard, it is necessary 
to state that a significant difference exists between the skills of a director and the characteristics (also behavior) of a director that make him or her contribute effectively to board performance. Clearly, the combination of requisite skills and desirable characteristics will determine the value of a director's contribution to organizational success.

There are quite a number of empirical studies on board characteristics or attributes as influencer of firm performance (see Garcia-Martin \& Herrero, 2018; Horvath \& Spirollari, 2012; Imade, 2019; Nguyen et al., 2017; Pereira \& Filipe, 2014). This strand of literature focuses on examination of board size, board gender diversity, board activity, independent or non-executive directors, insider ownership, board age, chief executive officer (CEO) duality, and audit committee on firm performance.

However, unobservable characteristics of board directors in relation to firm performance have not yet received rigorous study in the empirical literature. Gantenbein and Volonte (2011, p. 3) alluded to this by stating that studies "do not often address director skills, because detailed data of these characteristics is not readily available, and personal factors (e.g., talent) are either not observable or difficult to proxy". The concern of this paper, therefore, is to fill this empirical gap in knowledge. Specifically, the paper focuses on board directors' unobservable characteristics and how well they influence firm performance.

To mitigate the concerns for lack of proxy, this study deviated from the traditional methodology of ordinary least square and panel data regression. It adopted the generalized auto-regressive conditional heteroscedasticity (GARCH) model wherein the residuals of observed characteristics are taken as proxy for unobserved characteristics and modeled as conditional variance of firm performance. The study also tests the sensitivity of the model to three different measures of firm's financial performance, namely Tobin Q, return on assets (ROA), and share price. It is hoped that this effort will contribute to building a body of literature on directors' unobservable characteristics and the financial performance of firms.

\section{LITERATURE REVIEW}

The functions the board of directors should undertake can be viewed from any of four perspectives, namely: legal, resource dependence, class hegemony, and agency theory (Pereira \& Filipe, 2014). From the legal perspective, board can influence the performance of their companies if they carry out their required responsibilities. Such responsibilities include selecting the CEO, setting executive compensation and the strategy of the firm, nominating new directors, and monitoring. Board can also provide inter-organizational relationship. Board is also a means of keeping capitalist elite power, and a corporate control system to dissuade executives from opportunistic behavior.

A significant amount of board time is spent on technical processes relating to board's procedures and responsibilities, as well as control structures. This need for supervision and monitoring affects board size, independence, and diversity (GarciaMartin \& Herrero, 2018). The corporate governance codes have some prescriptions on the ap- propriate size of a board, which is a function of the industry and firm characteristics measured by its complexity. However, there is no unanimity in the empirical literature on the influence of board size on firm performance. While Lehn, Patro, and (2009), Ironkwe and Adee (2014), and Kyere and Ausloos (2020) made a case for large boards because this affords higher standard of advice, Shrivastav and Kalsie (2020) differ by stating that reaching a consensus in decision making with large boards is difficult and may also lead to the inhibition of the director.

On independence, the argument is whether executive directors have greater knowledge of the business and the company than non-executive directors. Coles, Daniel, and Naveen (2008) are of the view that executive directors have more and better information when it comes to specific aspects of the company. Olatunji and Ojeka (2011) added that because of the part-time nature of non-executive directors, they are too busy and committed to too many things at a time. Shrivastav and Kalsie (2020) found a significant negative impact 
of independent directors on firm performance. Contrary to this view, Boone et al. (2007) advocate for more non-executive directors as they provide better advice and have greater experience, which they bring from other sectors. Farag and Mallin (2017) reported a positive relationship between firm performance and the number of independent directors. Due to their independence, they tend to be more loyal as they are chosen in accordance with the interest of shareholders. Imade (2019) is of the view that non-executive directors provide objective criticism because they have legal duties like their executive counterparts. The study further notes that the Central Bank of Nigeria's code of corporate governance requires non-executive directors to, among other things, have broad experience, integrity, and independent judgment to make them dispassionate on issues of key appointments and evaluation of strategic performance.

Board composition should promote diversity wherein different attributes, characteristics, and levels of experience are combined. Aligning with this view, Umar and Sani (2020) found significant relationship between board composition and firm performance measured by ROA. Campbell and Minguezvera (2008) found a significant positive relationship between percentage of women in the board and Tobin Q. Adams and Ferreira (2009) submit that greater gender diversity exhibits higher degree of attendance at board meetings and attendance is a matter of commitment. Akpan and Amran (2014), and Bianco et al. (2015) opine that women bring resources like skills, prestige, and connection to external resources to the board. On board activity, normally approximated by frequency of board meeting, it has been observed that too frequent meetings signal some communication issues (Horvath \& Spirollari, 2012).

Studies have shown that market reacts to individual director characteristics. Reaction to the expertise of the director that is newly appointed was investigated by Defond et al. (2005) found the reaction to be significantly positive for expertise in finance. With respect to news about appointment of an independent director, Fich and Shivdasani (2006) reported insignificant reaction. However, the study found that when a CEO of other companies is an appointed outside director, the market reacts positively and significantly. This evidence suggests that market evaluates the ability of a new director to contribute to the board. However, market reaction is positive if only the new outside director is truly independent, that is, where the director is nominate by the board. The contribution of members of the board has also been found to depend on the information processing loads by the members (Khanna et al., 2014).

Board members' education and performance of firms have also been examined. For instance, Francis et al. (2015) found that having academic professors on the board correlate with performance in the areas of higher information conveyed by stock price and lower CEO compensation. This performance was attributed to the advising capability. In the same vein, Ujunwa (2012) reported that higher level of education of directors has a positive association with firm's outcomes. Nguyen et al. (2017) also found evidence of human capital adding value to the firm for publicly listed companies.

There is growing recognition that the character of the individual director that makes up the board is crucial to the success of the board. The characteristics of a director will determine whether he or she will contribute effectively to board performance. Characteristics describe the behavioral traits of individual directors the aggregate of which provides the raw ingredients for a high performing board (Reio \& Callahan, 2004). These characteristics can be categorized either into observable or unobservable ones. This is analogous to KPMG (2001) hard and soft personal profile factors of directors where experience, know-how, education, and expertise (financial, industrial, and international experience) are viewed as hard profile factors, while integrity and credibility as soft profile factors. These profile requirements could be specified by the firm, regulations, and legal compliance as boards today, than never before, are subject to duties of diligence due to increasing threats of litigation (Gantenbein \& Volonte, 2011).

The literature is not mute on director's emotion and firm performance. According to Scherer (2005), emotions are generally stimulus events. This implies that something happens to the individual that stimulates or triggers a response after having been evaluated for its significance. 
Emotion is event focused, appraisal driven, and has behavioral impact in that it prepares adaptive action tendencies. An individual's emotional state could affect work performance. The degree to which one experiences feelings such as sadness, happiness, and anger is a strong predictor of job performance (Reio \& Kidd, 2006). Researches support the fact that emotions, mood, and affect influence performance as they contribute to attitudinal and cognitive decisions about job satisfaction (Reio \& Callahan, 2004). Judge, Heller, and Mount (2002) have also found that neuroticism as a personality trait correlates with job satisfaction.

A director's commitment can be associated with performance. Commitment is the strength in identifying and integrating oneself into the organization. Toban and Sjahuruddin (2016) found three dimensions of commitment that affect performance: identification with the organization that manifests in the form of trust, involvement in work activities that make the individual ready and happy to cooperate with others, and loyalty wherein organizational interest is placed ahead of personal interest with no expectation of reward (Zehir et al., 2012).

Interpersonal relationship and communication skills of a director have also been linked with performance. Relationship is the wheel on which organization as a system function. Workplace performance relationships, and indeed board relationships, are interpersonal relationships involving individuals in the process of performing their tasks (Abe \& Mason, 2016). In interpersonal relationship, there is psychological orientation and interdependence (Deutsch, 2011). Bowen, Holden, and Lynch (2010) are of the view that interpersonal connection affects knowledge transfer between individuals. Emotionally involved individuals put more time and effort on behalf of each other. This can diminish opportunistic behavior and encourage more open communication, greater information sharing, and hence firm performance. Interpersonal relationship is closely coupled with interpersonal communication patterns. The development and growth of interpersonal relationship is affected by communication process and the form it takes (Abe \& Mason, 2016).

In the light of the extant literature reviewed, the motivation of this paper is to measure the impact of unobservable characteristics on corporate performance. To facilitate empirical investigation, the study hypothesized, in the null form, that board directors' unobservable characteristics have no significant impact on performance measured respectively by Tobin Q, ROA, and share price.

\section{METHODS}

This study used data of twenty-three (23) listed companies from the financial services sector of the Nigerian Stock Exchange (NSE) for a thirteen (13)-year period from 2006 to 2018. The selected firms are those who have had active trading on their shares, are under the regulation of Securities and Exchange Commission (SEC) Code of corporate governance, and have published annual reports with corresponding financial data. The required data were collected from the annual reports and NSE Fact book.

The dependent variable for this study is financial performance of a firm. A mix of financial performance proxies is employed. Tobin Q was used as a market-based proxy. ROA was used as an accounting-based measure, and share price as a market performance measure. Using alternative measures of performance provide rich information for analysis (Farag \& Mallin, 2017; Garcia-Martin \& Herrero, 2018; Pereira \& Filipe, 2014). For instance, accounting profit reflects economic profitability, while Tobin $\mathrm{Q}$ focuses on future prospect, and share price captures investors' perception of the well-being of the firm.

The methodological framework of the study is to model unobservable characteristics as the fixed effect or the stochastic element of observable characteristics. To this end, the independent variables are board's observable characteristics that bear on unobservable characteristics like interpersonal relation, communication skills, emotions, commitments, and loyalty. This study focuses on board activity, board gender diversity, board size, and board independence as the independent variables. Furthermore, prior year performance or the one-period lagged dependent variable is used as one of the explanatory variables. This can control for the dynamic nature of governance-performance relation and problem of auto-regres- 
sion (Khanna et al. 2014; Nyugen et al. 2017) and enhances model performance in a dynamic system generalized method of the moment model (Wintoki et al., 2012).

This study adopts a dynamic modeling framework of the GARCH model. In this type of model, the conditional variance is a function of variables that are in the information set available at time $t$. This model extends the basic ARCH model (Bollerslev, 1986). The GARCH (1 1) model specified for this study is:

$$
\begin{aligned}
& Y_{t}=\alpha_{0}+\alpha_{1} Y_{t-1}+\alpha_{2} \text { Bact }+ \\
& +\alpha_{3} \text { Bgen }+\alpha_{4} \text { Bsiz }+ \\
& +\alpha_{5} \text { Bind }+u_{t}, \\
& \frac{u_{t}}{\phi_{t}} \cong \operatorname{iidN}\left(0, h_{t}\right), \\
& h_{t}=\beta_{0}+\beta_{1} u_{t-1}^{2}+\beta_{2} h_{t-1}, \\
& \beta_{0}>0, \beta_{1} \geq 0, \beta_{2} \geq 0,
\end{aligned}
$$

where $Y_{t}=$ Firm's financial performance at time $t, Y_{t-1}=$ One-period lagged value of $Y_{t}$, Bact = Board activity, Bgen = Board gender diversity, $B s i z=$ Board size, Bind $=$ Board independ ence, $u_{t}=$ Stochastic term, $\alpha_{0} \ldots \alpha_{5}=$ Estimated coefficients of mean equation, and $\beta_{0} \ldots \beta_{2}=$ Estimated coefficients of conditional variance.

Specifically, equation (1) is called the mean equation and equation (2) is the variance equation. The $u_{t}$ is the fixed effect, which is an unobservable component. And given the information set $\left(\phi_{t}\right)$ available at a particular point in time, it is independently and identically distributed with zero mean and variance $h_{t}$. The analysis of the unobservable director-level heterogeneity will illuminate whether unobserved features influence firm performance.

The variance equation shows that the scaling parameter $h_{t}$, depends on the past values of the shock captured by the lagged square residual term $u_{t-1}^{2}$ and on its own past value $h_{t-1}$. Now, to ascertain the influence of unobservable characteristics on firm performance, the coefficient $\beta_{2}$ should be

\begin{tabular}{|c|c|}
\hline Variable & Definition and measurement \\
\hline \multicolumn{2}{|r|}{ Dependent variables } \\
\hline Tobin Q & $\begin{array}{l}\text { It is the ratio of the sum of the market value } \\
\text { of the firm's shares and book value of debt to } \\
\text { book value of total assets }\end{array}$ \\
\hline $\begin{array}{l}\text { Return on } \\
\text { Assets }(R O A)\end{array}$ & $\begin{array}{l}\text { It is a measure of the profitability of a firm } \\
\text { in relation to its total asset and computed as } \\
\text { net income divided by year end assets }\end{array}$ \\
\hline Share price (SPx) & $\begin{array}{l}\text { This is the closing price of the share as at the } \\
\text { last trading day of the year }\end{array}$ \\
\hline \multicolumn{2}{|r|}{ Independent variables } \\
\hline $\begin{array}{l}\text { Board activity } \\
\text { (Bact) }\end{array}$ & $\begin{array}{l}\text { Approximated by board meeting, it is the } \\
\text { number of regular meetings held by the } \\
\text { board in a fiscal year }\end{array}$ \\
\hline $\begin{array}{l}\text { Board gender } \\
\text { diversity (Bgen) }\end{array}$ & $\begin{array}{l}\text { This is the proportion of women in the board } \\
\text { or alternatively, the number of women in the } \\
\text { board }\end{array}$ \\
\hline Board size (Bsiz) & The total number of directors on the board \\
\hline $\begin{array}{l}\text { Board } \\
\text { independence } \\
\text { (Bind) }\end{array}$ & $\begin{array}{l}\text { It is measured by the proportion of } \\
\text { independent directors to the size of the } \\
\text { board. Independent directors, and also non- } \\
\text { executive, external, or outside directors, are } \\
\text { not employees of the company and have no } \\
\text { material relationship with it }\end{array}$ \\
\hline$Y_{t-1}$ & $\begin{array}{l}\text { One period lagged value of a dependent } \\
\text { variable }\end{array}$ \\
\hline
\end{tabular}
positive and statistically significant. The model was estimated respectively for the different proxies of the dependent variable.
Table 1. Variable definition and measurement

Source: Authors

\section{RESULTS}

The results of the descriptive statistics to illuminate the data are presented in Table 2.

Three proxies were used to measure the dependent variable, namely Tobin Q, ROA, and SPx. The mean value for Tobin Q is 1.071472 , while that of ROA is $1.766020 \%$ and SPx is $\$ 5.55$. The minimum values for these variables are, respectively, $-0.27,-56.22 \%$, and $\mathrm{N} 0.20$, the corresponding maximum values are $10.84,115.51 \%$, and $\mathrm{N} 47.95$. The standard deviation, which measures the variability in the data shows quite a high value for ROA (10.64642) and SPx (8.674193), and a relatively low value for Tobin Q (1.258528). This implies that for ROA and SPx, there is a wide dispersion of the individual observations from their mean values. This is substantiated by the skewness values (5.204412, $2.208709,2.516544)$ and Kurtosis values (34.55501, $52.55008,9.735605)$, respectively. The three variables have the skewness value not equal to zero and kurtosis not equal to three. Therefore, they are positively skewed and leptokurtic, and have the tendency to rise than to fall. The Jarque-Bera sta- 
Table 2. Descriptive statistics

Source: Authors' computation.

\begin{tabular}{|c|c|c|c|c|c|c|c|}
\hline Statistics & Tobin Q & ROA & SPx & Bact & Bgen & Bsiz & Bind \\
\hline Mean & 1.071472 & 1.766020 & 5.552408 & 0.727154 & 13.77597 & 11.44147 & 62.41619 \\
\hline Maximum & 10.84000 & 115.4100 & 47.95000 & 1.114000 & 60.00000 & 21.00000 & 90.91000 \\
\hline Minimum & -0.270000 & -56.22000 & 0.200000 & 0.301000 & 0.000000 & 3.000000 & 0.000000 \\
\hline Std deviation & 1.258528 & 10.64642 & 8.674193 & 0.108469 & 11.79872 & 3.529229 & 12.95647 \\
\hline Skewness & 5.204412 & 2.208709 & 2.515644 & 0.457224 & 0.686845 & 0.056158 & -0.330609 \\
\hline Kurtosis & 34.55501 & 52.55008 & 9.735605 & 3.762173 & 2.952597 & 2.767767 & 4.185377 \\
\hline Jarque-Bera & 13754.78 & 30830.94 & 880.5828 & 17.65499 & 23.53720 & 0.829065 & 22.95234 \\
\hline Probability & 0.000000 & 0.000000 & 0.000000 & 0.000147 & 0.000008 & 0.660649 & 0.000010 \\
\hline Number of obs. & 299 & 299 & 299 & 299 & 299 & 299 & 299 \\
\hline
\end{tabular}

tistic shows if a variable is approximated by normal distribution. The probability value for each of the three variables is zero, meaning that none of the variables is normally distributed.

For the independent variables, the mean value of board activities measured by board meetings is 0.727154 (equivalent to 6 times when the log-value is transformed to the real number). The minimum value is 0.301 (approximately 2 times) and maximum value is 1.114 (approximately 13 times). The standard deviation (0.108468), skewness (0.457224), and kurtosis (3.762173) revealed a mild variability in this variable. Be that as it may, the Jarque-Bera statistic shows that it is not approximated by normal distribution.

Board gender diversity shows an average of $13.77579 \%$ board members as women. The maximum value is $60 \%$, while the minimum value is zero percent. The standard deviation is 11.79872 , and the positive skewness (0.457224) shows that the percentage of women in the board exhibits tendency to increase. Again, this variable is not normally distributed. Board independence captured by the proportion of non-executive directors, has a mean value of $62.41619 \%$, and maximum value of $90.91 \%$. The skewness value is negative $(-0.330609)$, implying that this variable shows sign of decrease. Again, the kurtosis value and Jarque-Bera statistics did not establish normal distribution.

Board size has a mean value of 11.44147. Implicitly, board is composed of an average of 11 members, with minimum of three and maximum of 21 members. The Jarque-Bera statistic of this variable shows that it is normally distributed. This is so because the probability value ( 0.660649$)$ exceeds the $5 \%$ level of significance. This result is confirmed by the skewness and kurtosis values, which are approximately zero and three, respectively. In sum, the fact that the majority of the variables are not normally distributed suggests that non-linear models will be more appropriate to the data.

In addition to the descriptive statistics, the study also presents the correlation matrix, which shows how the variables relate with one another. The result is presented in Table 3 .

From Table 3, Tobin $Q$ has a negative relationship with all other variables. The implication of this is that the explanatory variables do not contribute to firm performance measured by Tobin Q. Also, board independence is negatively correlated with

Table 3. Correlation matrix

\begin{tabular}{|c|c|c|c|c|c|c|c|}
\hline Variable & Tobin $Q$ & ROA & SPX & Bact & Bgen & Bsiz & Bind \\
\hline Tobin $Q$ & 1.000000 & & & & & & \\
\hline ROA & -0.149417 & 1.000000 & & & & & \\
\hline SPx & -0.014258 & 0.057832 & 1.000000 & & & & \\
\hline Bact & -0.144791 & -0.045619 & -0.117348 & 1.000000 & & & \\
\hline Bgen & -0.167980 & 0.103589 & 0.129184 & 0.045751 & 1.000000 & & \\
\hline Bsiz & -0.368572 & -0.048424 & 0.238604 & 0.192366 & 0.070249 & 1.000000 & \\
\hline Bind & -0.094014 & -0.096492 & -0.218749 & -0.018936 & -0.118289 & -0.217028 & 1.000000 \\
\hline
\end{tabular}


the other variables. This implies that the presence of independent directors on the board decreases firm performance. This result is not at variance with the submissions of Horvath and Spirollari (2012) and Garcia-Martin and Herrero (2018). Board size is positively related to the share price measure of performance, but negatively related to Tobin Q and ROA. Clearly, none of the correlation coefficients exceeds 0.9 ; therefore, there is no a multicollinerity problem (Tabachnick \& Fidel, 2007). The highest correlation is 0.238604 , which is between board size and share price.

\subsection{Empirical results}

The results of the estimation of the model captured by equations (1) and (2) are presented here to ascertain the impact of director unobservable characteristics on the performance of the firm. The model is estimated for Tobin Q, ROA, and share price, respectively, as dependent variables to illuminate the sensitivity to different proxies of performance.

\subsubsection{Model Result - Tobin Q as a Performance Measure}

Table 4. Result of the model with Tobin $Q$ as a performance measure

Source: Authors' computation.

\begin{tabular}{l|c:c:c}
\hline Mean equation & Coefficient & z-statistic & Probability \\
\hline & \multicolumn{3}{c}{ Variable } \\
\hline C & 1.068836 & 15.11275 & 0.0000 \\
\hline TobinQ(-1) & 0.555281 & 15.57964 & $0.0000^{* * *}$ \\
\hline Bact & 0.212035 & 3.380471 & $0.0007 * * *$ \\
\hdashline Bgen & -0.007747 & -13.97763 & $0.0000^{* * *}$ \\
\hline Bsiz & -0.001918 & -0.715735 & 0.4742 \\
\hline Bind & -0.013501 & -26.46572 & $0.0000^{* * *}$ \\
\hline & Variance equation & \\
\hline C & 0.031741 & 4.927748 & 0.0000 \\
\hline$\beta_{1}$ & 4.131807 & 12.20781 & $0.0000^{* * *}$ \\
$\beta_{2}$ & 0.013833 & 1.007769 & 0.3136 \\
\hline
\end{tabular}

Note: $* * *$ denote significance at $1 \%$.

In the mean equation panel, the coefficient of lagged value of performance TobinQ(-1) is positive and statistically significant at $1 \%$. This implies that current performance is influenced by past performance. Board activity is positive $(0.212035)$ and significant. Board gender is negative $(-0.007747)$ and significant. Board size is negative $(-0.001918)$ but not significant. Board independence is neg- ative (-0.013501) and significant. Clearly, while board activity significantly increases the performance of the firm, the other director-level variables reduce firm performance.

In the variance equation panel, the lagged value or residual squared $\left(\beta_{1}\right)$, which is also called the ARCH term, transmits news about the variation in firm performance. This value is positive (4.131807) and also significant. $\beta_{2}$, which is also called the GARCH term, is the estimate of the influence of director unobservable characteristics on firm performance. This estimate is positive $(0.013833)$ but not statistically significant as the probability value of the $\mathrm{z}$-statistic $(0.3136)$ is greater than the 0.05 level of significance. Therefore, with the result of this model, directors' unobservable characteristics do not significantly influence performance.

\subsubsection{Model Result - ROA as a Performance Measure}

Table 5. Result of the model with ROA as a performance measure

Source: Authors' computation.

\begin{tabular}{|c|c|c|c|}
\hline Mean equation & Coefficient & z-statistic & Probability \\
\hline \multicolumn{4}{|c|}{ Variable } \\
\hline $\mathrm{C}$ & 3.502925 & 1.901900 & 0.0572 \\
\hline$R O A(-1)$ & 0.051693 & 1.146834 & 0.2515 \\
\hline Bact & -4.770501 & -3.098727 & $0.0019 * * *$ \\
\hline Bgen & 0.054324 & 3.653445 & $0.0003^{* * *}$ \\
\hline Bsiz & 0.184773 & 4.292401 & $0.0000 * * *$ \\
\hline Bind & -0.029240 & -2.209989 & $0.0271^{* *}$ \\
\hline \multicolumn{4}{|c|}{ Variance equation } \\
\hline C & 1.172811 & 4.532007 & 0.0000 \\
\hline$\beta_{1}$ & 0.930433 & 5.556086 & $0.0000 * * *$ \\
\hline$\beta_{2}$ & 0.490237 & 10.77734 & $0.0000 * * *$ \\
\hline
\end{tabular}

Results in the mean equation panel show that the lagged value of performance captured by $\mathrm{ROA}(-1)$ does not significantly influence current performance. The coefficient is 0.051693 (positive) with probability value of 0.2515 (which is greater than 0.05 ). For other explanatory variables, board activity and board independence are negative and statistically significant at $1 \%$ and $5 \%$, respectively. Gender diversity and board size are positive (0.054324 and 0.184773 , respectively) and significant at $1 \%$. Accordingly, these variables increase firm performance. 
The variance equation reveals that $\beta_{1}$, the lagged residual squared (0.930433), is positive and significant. Therefore, the news announcement effect is positive and significant. The estimate of director unobservable characteristics $\beta_{2}$, is positive (0.490237) and significant. With this result, unobservable characteristics significantly increase firm performance as determined by return on assets.

\subsubsection{Model Result - Share Price as a Performance Measure}

Table 6. Result of the model with share price as a performance measure

Source: Authors' computation.

\begin{tabular}{|c|c|c|c|}
\hline Mean equation & Coefficient & z-statistic & Probability \\
\hline \multicolumn{4}{|c|}{ Variable } \\
\hline C & -4.433568 & -7.740451 & 0.0000 \\
\hline$S P X(-1)$ & 0.498362 & 21.04525 & $0.0000^{* * *}$ \\
\hline Bact & 1.660047 & 3.288926 & $0.0010^{* * *}$ \\
\hline Bgen & 0.019271 & 3.571110 & $0.0004^{* * *}$ \\
\hline Bsiz & 0.424720 & 11.23093 & $0.0000 * * *$ \\
\hline Bind & 0.008195 & 1.900022 & 0.0574 \\
\hline \multicolumn{4}{|c|}{ Variance equation } \\
\hline C & 0.608798 & 1.841624 & 0.0655 \\
\hline$\beta_{1}$ & 2.201264 & 7.157725 & $0.0000 * * *$ \\
\hline$\beta_{2}$ & 0.181676 & 4.133184 & $0.0000 * * *$ \\
\hline
\end{tabular}

Note: $* * *$ denote significance at $1 \%$.

The mean equation result shows that all the coefficients of the explanatory variables are positive. This means that they increase firm performance. Again, all explanatory variables apart from independence of the board are significant. A look at the variance equation result shows that the news effect of director unobservable characteristics is positive $\left(\beta_{1}=2.201264\right)$ and significant. Now, the statistical significance of unobservable characteristics for firm performance ascertained from $\beta_{2}$ shows that this coefficient is positive (0.181676) and statistically significant at $1 \%$. Clearly, this result implies that director unobservable characteristics significantly increase firm performance.

\section{DISCUSSION}

The results of the analysis of the models for different dimensions of performance show that the result is sensitive to a proxy used for firm performance. While unobservable characteristics were not significant in explaining firm performance on the dimension of Tobin Q, it was highly significant on the dimensions of ROA and share price. Therefore, the mix result in some prior studies is due partly to different proxies for firm performance. Using Tobin $\mathrm{Q}$ to measure performance, this result did not support Shabbir (2018) in the area of board gender diversity and board independence. It also did not support Gantenbein and Volonte (2011) and Fernau (2013) in gender diversity. However, this study agrees with GarciaMartin and Herrero (2018) on board size, board independence, and gender diversity. The finding on board size is also in line with Fernau (2013) and Nguyen et al. (2017).

Using ROA as a proxy for performance, the result of this paper is consistent with Garcia-Martin and Herrero (2018), Nguyen et al. (2017), Umar and Sani (2020), and Zakaria, Purhanudin, and Palanimally (2014) on board size. On gender diversity and board independence with ROA as a performance variable, this study agrees with GarciaMartin and Herrero (2018). It also agrees with Zakaria et al. (2014) on board independence. On share price, the result is in line with Ironkwe and Adee (2014) and Kyere and Ausloos (2020). The result that greater board independence leads to lower firm performance is attributable to the lack of specific knowledge by independents for specific industries, which reduces their efficiency. The overall finding that director unobservable characteristics influence firm performance reinforces the earlier submissions by Gantenbein and Volonte (2011) and Fernau (2013) that director's fixed effect or unobserved managerial heterogeneity are important in the explanation of firm performance.

\section{CONCLUSION}

In this paper, an attempt has been made to investigate the complex link between characteristics of board directors that are not readily observable and the performance of the firm. This is against the backdrop that corporate boards are no longer mere presiding institutions, but are an active instrument for the strategic development of the firm. To palliate the lack of proxies, this study mirrors the unobserva- 
ble characteristics through observable board attributes like board meeting frequency, gender diversity, size of the board, and independence of the board. With this approach, the study did not find a linear modeling framework appropriate. Therefore, it adopted dynamic non-linear autoregressive model that enables the modeling of the stochastic component of the observable characteristics as an unobservable component. This is a novelty in this area of study. The study found that unobservable characteristics significantly influence firm performance in the ROA and share price dimensions. In the Tobin Q dimension, though, there was a positive relationship, but it was not significant. Thus, the result is robust and sensitive to performance proxies.

Despite the significant effort made by this study, it is limited by the fact that it used data from only the financial services sector of the Nigerian economy, and over a relatively recent period of thirteen (13) years from 2006 to 2018. Therefore, further investigations are needed using longer period data from several sectors of the Nigerian stock market.

\section{AUTHOR CONTRIBUTIONS}

Conceptualization: Henry Osahon Osazevbaru.

Data curation: Henry Osahon Osazevbaru.

Formal analysis: Emmanuel Mitaire Tarurhor.

Funding acquisition: Henry Osahon Osazevbaru, Emmanuel Mitaire Tarurhor.

Investigation: Emmanuel Mitaire Tarurhor.

Methodology: Emmanuel Mitaire Tarurhor.

Resources: Henry Osahon Osazevbaru.

Software: Emmanuel Mitaire Tarurhor.

Supervision: Henry Osahon Osazevbaru.

Validation: Henry Osahon Osazevbaru.

Writing - original draft: Henry Osahon Osazevbaru, Emmanuel Mitaire Tarurhor.

Writing - review \& editing: Henry Osahon Osazevbaru, Emmanuel Mitaire Tarurhor.

\section{REFERENCES}

1. Abe, I. I., \& Mason, R. B. (2016). The role of individual interpersonal relationships on work performance in the South African retail sector. Problems and Perspectives in Management, 14(2), 192-200. http://dx.doi. org/10.21511/ppm.14(21). 2016.08

2. Adams, R., \& Ferreira, D. (2009). Women in boardroom and impact on governance and performance. Journal of Financial Economics, 94(1), 291-309. Retrieved from https://www.researchgate.net/ publication/5098676_Women_in_ the_Boardroom_and_Their_Impact_on_Governance_and_Performance

3. Akpan, E. O., \& Amran, N. A. (2014). Board characteristics and company performance: Evidence from Nigeria. Journal of Finance and Accounting, 2(3), 81-89. Retrieved from https:// www.researchgate.net/publication/263393528_Board_characteristics_and_company_performance_Evidence_from_Nigeria

4. Bianco, M., Ciavarella, A., \& Signoretti, R. (2015). Women in corporate boards in Italy: The role of family connections. Corporate Governance an International Review, 23, 1-16. Retrieved from https://www.researchgate.net/publication/268528780_Women_on_ Corporate_Boards_in_Italy_The_ Role_of_Family_Connections

5. Bollerslev, T. (1986). Generalized autoregressive heteroscedasticity. Journal of Econometrics, 31, 307327. https://doi.org/10.1016/03044076(86)90063-1

6. Boone, A. L., Casares-Field, L., Karpoff, J. M., \& Raheja, C. (2007).
The determinants of corporate board size and composition: An empirical analysis. Journal of Financial Economics, 85(1), 66-101. https://doi.org/10.1016/j. jineco.2006.05.004

7. Bowe, L., Holden, M. T., \& Lynch, P. (2010). Understanding the influence of interpersonal relationship, interpersonal communication patterns and contextual factors on tacit knowledge transfer efficiency in business networks. Waterford Institute of Technology. Retrieved from https://www.researchgate. net/publication/277190394_UNDERSTANDING_THE_INFLUENCE_OF_INTERPERSONAL RELATIONSHIPS INTERPERSONAL_COMMUNICATION_ PATTERNS_AND_CONTEXTUAL_FACTORS_ON_TACIT_ 
KNOWLEDGE_TRANSFER_EFFICIENCY_IN_BUSINESS_NETWORKS

8. Campbell, K., \& Minguez-Vera, A. (2008). Gender diversity in the boardroom and firm financial performance. Journal of Business Ethics, 83(2), 435-451. Retrieved from https://link.springer.com/article/10.1007/s10551-007-9630-y

9. Coles, J. L., Daniel, N. D., \& Naveen, L. (2008). Boards: Does one size fit all? Journal of Financial Economics, 87(1), 329-356. https://doi.org/10.1016/j.jfineco.2006.08.008

10. Defond, M. L., Hann, R. N., \& Hu, X. (2005). Does the market value financial expertise on audit committees of boards of directors? Journal of Accounting Research, 43(2), 153-193. Retrieved from https://www.jstor.org/ stable/3542339? seq=1

11. Deutsch, M. (2011). Interdependence and psychological orientation. In Conflict, Interdependence and Justice (pp. 247-271). New York: Springer, Retrieved from https://link.springer.com/chapter/10.1007/978-3-319-15440-4_5

12. Farag, H., \& Mallin, C. (2017) Monitoring corporate boards: Evidence from China. The European Journal of Finance, 22(1), 27-49. https://doi.org/10.1080/135 1847X.2017.1369138

13. Fernau, E. (2013). Executive attributes, director attributes, and firm performance. University of Mannheim, Germany. Retrieved from http://www.fmaconferences. org/Maastricht/Papers/131202_ Executive_Attributes.pdf

14. Fich, E. M., \& Schivdasani, A. (2006). Are busy boards effective monitors? Journal of Finance, 61(2), 689-724. https://doi.org/10.1111/j.15406261.2006.00852.x

15. Francis, B., Hassan, I., \& Wu, Q. (2015). Professors in the boardroom and their impact on corporate governance and firm performance. Financial Management, 44(3), 547581. https://doi.org/10.1111/ fima. 12069
16. Gantenbein, P., \& Volonte, C. (2011). Director characteristics and firm performance. University of Basel, Faculty of Business and Economics (Working Paper 11). Retrieved from https:// www.researchgate.net/publication/228248811_Director_Characteristics_and_Firm_Performance

17. Garcia-Martin, C. J., \& Herrero, B. (2018). Board of directors: composition and effect on performance of the firm. Economic Research-Ekonomska, 31(1), 1015-1041. https://doi.org/1 0.1080/1331677X.2018.1436454

18. Horvath, R., \& Spirollari, P. (2012). Do the board of directors' characteristics influence firm performance? The U.S evidence. Prague Economic Papers 4, 470486. https://doi.org/10.18267/j. pep. 435

19. Imade, O. G. (2019). Board gender diversity, non-executive director's composition and corporate performance: Evidence from listed firms in Nigeria. African Journal of Business and Management, 13(9), 283-290. Retrieved from https://www.researchgate.net/ publication/333722548_Board gender_diversity_non-executive_directors_composition_and_ corporate_performance_evidence_ from_listed_firms_in_Nigeria

20. Ironkwe, U., \& Adee, G. M. (2014). Corporate governance and financial firms' performance in Nigeria. Journal of Exclusive Management Science, 3(8), 1-6. Retrieved from https:// www.researchgate.net/publication/228241113_Corporate_Governance_and_Firms'_Performance_in_Nigeria

21. Judge, T. A., Heller, D., \& Mount, M. K. (2002). Five factor model of personality and job satisfaction: A meta-analysis. Journal of Applied Psychology, 87(3), 530541. Retrieved from https:// www.researchgate.net/publication/11284305_Five-Factor_Model_of_Personality_and_Job_ Satisfaction_A_Meta-Analysis

22. Khanna, P., Jones, C. D., \& Boivie, S. (2014). Director human capital, information processing demands, and board effectiveness. Journal of Management, 40(2), 557-585. https://doi.org /10.1177\%2F0149206313515523

23. KPMG (2001). Corporate governance in der Schweiz, Verwaltungsrat - Zwischen Verantwortung und Haftung. Zurich: KPMG Fides Management AG.

24. Kyere, M., \& Ausloos, M. (2020). Corporate governance and firms' financial performance in the United Kingdom. International Journal of Finance and Economics, 10(1), 1-15. https://doi. org/10.1002/ijfe.1883

25. Lehn, K. M., Patro, S., \& Zhao, M. (2009). Determinants of the size and composition of U.S corporate boards: 1935-2000. Financial Management, 38, 747-780. https://doi.org/10.1111/j.1755053X.2009.01055.X

26. Nguyen, T., Nguyen, A., Locke, S., \& Reddy, K. (2017). Does the human capital of board directors add value to firm? Evidence from an Asian Market. Cogent Economics and Finance, 5, 138-155. Retrieved from https://www.researchgate.net/ publication/320133295_Does the_human_capital_of_board_directors_add_value_to_firms_Evidence_from_an_Asian_market

27. Olatunji, O. R., \& Ojeka, S. (2011). The role of non-executive directors in the profitability of banks in Nigeria. International Journal of Business and Management, 6(2), 104-127. Retrieved from http:// www.ccsenet.org/journal/index. $\mathrm{php} / \mathrm{ijbm} /$ article/view/9262

28. Pereira, V., \& Filipe, J. (2014). The board's attributes and their influence in company performance: A review over the recent literature. International Journal of Latest Trends in Finance and Economic Sciences, 4(1), 691-702. Retrieved from https://repositorio.iscte-iul.pt/ bitstream/10071/9577/1/publisher_version_912_3170_1_PB.pdf

29. Reio, T. G., \& Callahan, J. (2004). Affect, curiosity and socialization related learning: A path analysis of antecedents to job performance. 
Journal of Business and Psychology, 19(1), 3-22. Retrieved from https:// link.springer.com/article/10.1023/ B:JOBU.0000040269.72795.ce

30. Reio, T. G., \& Kidd, C. A. (2006). An exploration of the impact of employee job satisfaction, affect, job performance, and organizational financial performance: A review of literature. Retrieved from https:// eric.ed.gov/?id=ED492690

31. Scherer, K. R. (2005). What are emotions? And how can they be measured? Trends and Development: Research on Emotions, 44(4), 695-729. Retrieved from https://doi.org/10.1177\%2F0539018405058216

32. Shabbir, M. S. (2018). Women on corporate boards and firm performance, preliminary results from Italian listed companies after the introduction of Gender Quota Law 120/2011. Journal of Business and Financial Affairs, 7(1), 316-321. Retrieved from https://www.researchgate.net/ publication/324400533_Women_ on_Corporate_Boards_and_Firm Performance_Preliminary_Results_from_Italian_Listed_Companies_after_the_Introduction_of Gender_Quota_Law_1202011
33. Shrivastav, S. M., \& Kalsie, A. (2020). Corporate governance internal board mechanisms and firm performance: A panel level analysis in emerging market. International Journal of Advanced Science and Technology, 29(9), 2225-22240. Retrieved from http:// sersc.org/journals/index.php/ IJAST/article/view/14561

34. Tabachnick, B. G., \& Fidell, L. S. (2007). Using multivariate statistics ( $5^{\text {th }}$ ed.). USA: Pearson Education.

35. Toban, C., \& Sjahruddin, H. (2016). The antecedent and consequences of organizational commitment and job satisfaction. Journal of Business and Management, 4(2), 26-33. Retrieved from https://www.researchgate. net/publication/303329762_ The_Antecedent_and_Consequence_of_Organizational_Commitment_and_Job_Satisfaction

36. Ujunwa, A. (2012). Board characteristics and the financial performance of Nigerian quoted firms. Corporate Governance, 12(5), 45-55. https://doi. org/10.1108/14720701211275587

37. Umar, A. I. \& Sani, D. (2020). Effect of corporate governance on the performance of listed deposit money banks in Nigeria. Science Journal of Business and Management, 8(1), 35-40. Retrieved from https://www.researchgate.net/ publication/338783143_Effect_ of_Corporate_Governance_on_ Financial_Performance_of_Deposit_Money_Banks_in_Nigeria

38. Wintoki, M. B., Linck, J. S., \& Netter, J. M. (2012). Endogeneity and dynamics of internal corporate governance. Journal of Financial Economics, 105(1), 581-606. https://doi.org/10.1016/j. jfineco.2012.03.005

39. Zakaria, Z., Purhanudin, N., \& Palanimally, Y. R. (2014). Board governance and firm performance: A panel data analysis. Journal of Business Law and Ethics, 2(1), 1-12. Retrieved from http://jblenet. com/journals/jble/Vol_2_No_1_ June_2014/1.pdf

40. Zehir, C., Sehitoglu, Y., \& Erdogan, E. (2012). The effect of leadership and supervisory commitment to organizational performance. Procedia-Social and Behavioural Sciences, 58, 207-216. https://doi. org/10.1016/j.sbspro.2012.09.994 